\title{
Ecological effects of use biogas to supply the internal combustion engine in the electricity generation process - results of LCA analysis
}

Environmental life cycle assessment (LCA) in Poland is still a relatively new method of estimating the environmental impact of production processes. It enables the assessment of the environmental risks associated with the product system or activity, either through the identification and quantification of materials and energy used and waste introduced into the environment, as well as assess their impact on the environment. LCA method application also enables the calculation of greenhouse gas emissions in accordance with Directive 2009/28/EC on the promotion of energy from renewable sources.

This paper presents the results of the simplified life cycle analysis of electricity production process from agricultural biogas used as an engine fuel. LCA analysis was conducted based on data from one of the national biogas plants. The selection criterion was based on the availability of substrates (maize silage, distillery slop and sugar beet pulp) and the possibility of obtaining high quality data for analysis (actual data based on the existing biogas plant). In addition, the environmental impact of the biogas power generation technology obtained through the methane fermentation process only of waste materials (distillery slop, sugar beet pulp) and coprocessing of waste and maize silage was compared.

Key words: LCA, biogas, waste, combustion, electricity production

\section{Why LCA?}

One of the most popular definitions of LCA available in the literature is the definition proposed by Fava et al. According to this author environmental Life Cycle Assessment (LCA) is a technique designed to assess the environmental risks associated with the product system or activity, either by identifying and quantifying energy and materials used and wastes introduced into the environment, as well as the impact of those materials, energy and waste on the environment. The assessment relates to the whole life cycle of the product or the activity from the mining and mineral processing, product manufacturing process, distribution, use, re-use, maintenance, recycling up to the final use and transportation. LCA directs the study of environmental impact of the product system to the area of the ecosystem, human health and resources used [1-6].

The main advantage of this method is its complexity. It covers the whole life cycle of a product ("cradle to grave"). [6]. Depending on the level of detail of the analysis, it is possible to link all individual processes and estimate their impact on the environment. The method enable also for quantitative identification of all materials and energy consumed to produce the product, as well as particulate and gaseous emissions, noise and radiation emissions and waste generation, allowing efficient management of the production process and reducing economic and environmental costs. By using life cycle assessment it is possible to identify those processes, which generate the greatest environmental burden and their modification to reduce those burdens. The LCA also allows for economic costs reduction by optimizing LCC (Life Cycle Cost) [7-9]. Thanks to such a comprehensive and systematic approach to production processes, LCA has become such a popular and widely used management technique.

One of the most important advantage of LCA is it's versatility. LCA has been widely used in research for years, but an increasing role is also being played in industrial analysis.

\section{The aim and scope of the analysis}

This paper presents the results of the environmental life cycle analysis of electricity production from agricultural biogas used as an engine fuel. The biogas is obtain through $\mathrm{WtE}$ (waste-to-energy) processes. For the LCA analysis has been selected one of the existing national plant. In this biogas plant electricity and heat are produces in cogeneration. As a substrate for biogas production are use corn silage and wastes from food industry (distillery slop, sugar beet pulp). Additionally, a comparison of the environmental impact of electricity production from biogas produced through anaerobic digestion only waste materials (distillery slop, sugar beet pulp) and co-digestion of waste materials and silage corn was performed.

In the frame of analysis were identified two main stage:

- raw material stage - corn cultivation for silage production;

- technological stage taking into account all processes take place in biogas plant.

\subsection{Feedstock procurement}

For raw material stage LCA analysis was covered by the corn cultivation (the establishment of plantation, fertilization, plant protection and harvest), and the process of corn ensiling in order to creation of corn silage (Fig. 1). So prepared corn is a proper feedstock for biogas plant. In addition to the raw material stage transport of corn silage to biogas plant was also included. Other substrates, such as distillery slop or sugar beet pulp is treated as waste in other manufacturing processes, and therefore (according to the methodology), it is assumed that their production is not an additional burden on the environment.

In the case of dedicated crops it is necessary to incur adequate material and energy expenditure. At the stage of maize cultivation, the following sub-stages were included in the calculations: treatments related to establishment of plantation, fertilization, plant protection and harvesting, as well as transport of maize to biogas and silage preparation. 
All treatments and their unit processes are within the scope of the LCA analysis system.

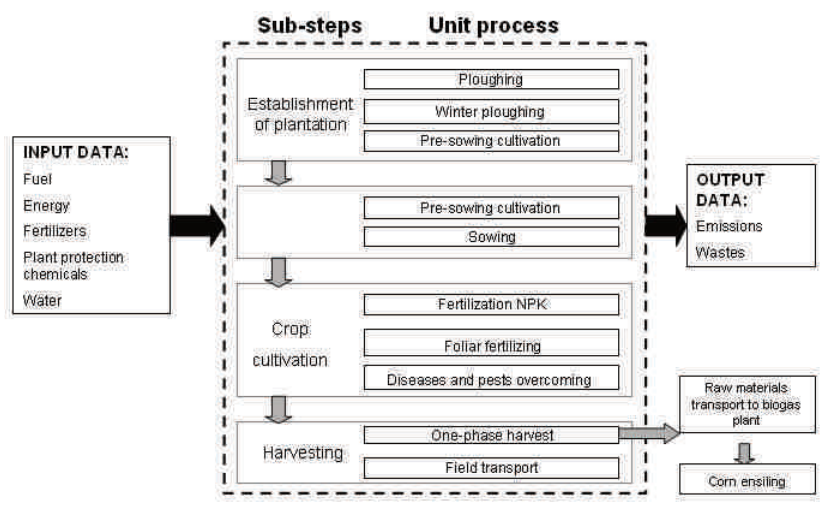

Fig. 1. The general scheme taking into account the system boundaries and functional unit of corn cultivation process and the silage formation

In the case of dedicated crops, the use of fertilizers and plant protection products is very important, as well as the inclusion in the system boundaries their production as extremely energy-consuming and causing high emissions.

Transport of maize to biogas plant is linked to fuel consumption in the form of diesel fuel.

In addition to the above-mentioned unit processes within the system boundaries was include the production of fertilizers and fuel (ON) used in field operations because on their significant impact of these components on the outcome of the environmental analysis and associated greenhouse gas emissions.

Outside the system borders were processes such as the production of plant protection products, the manufacture of agricultural machinery and the transport of seeds to the field.

Production of plant protection products, although it may affect the to the final result of the analysis, was not included in the system boundaries because of the lack of input data. The production of agricultural machinery has been excluded from the system boundaries as recommended in Annex V of 2009/28 / EC Directive, which contains guidelines for calculating the impact of biofuels, bioliquids and their fossil fuels equivalent on greenhouse gas emissions. In addition, it was considered that the determination of the assumptions underlying the magnitude of the impact of the mentioned processes was associated with too high recurrence.

For the raw material stage, a functional unit in the form of $1 \mathrm{Mg}$ maize silage (1 Mg silage) was adopted.

\subsection{Technological stage}

In the case of technological step scope of the analysis included the technology of electricity production from biogas used as an engine fuel. This stage consists of the following sub-stages (Fig. 2):

1. Transport of raw materials for biogas plant and their storage.

2. Raw materials preparation (corn ensiling, grinding, maceration, mixing).

3. Loading of raw materials for digester.
4. Methane fermentation (hydrolysis, acetogenesis, octanogenesis, methanogenesis).

5. Storage of biogas.

6. Biogas purification.

7. Electricity and heat production.

8. Storage of digestate.

9. Management of digestate.

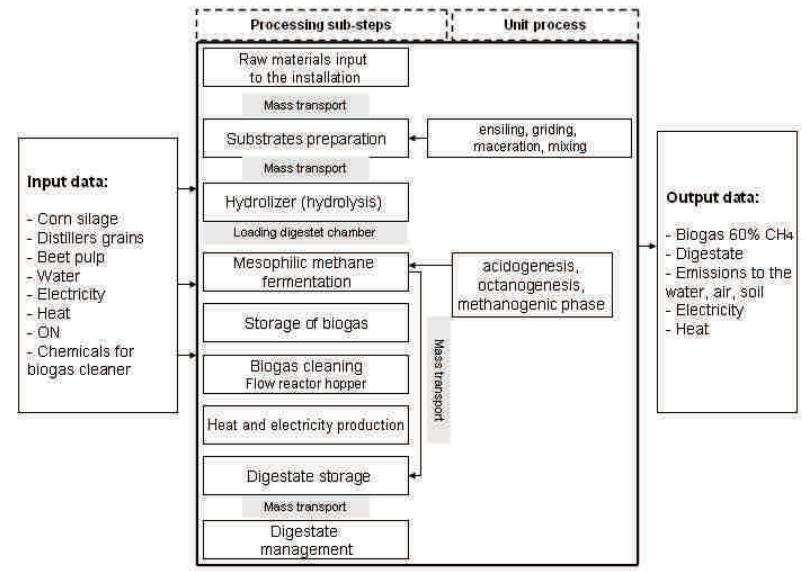

Fig. 2. The general scheme of biogas and electricity production

For technology stage in the scope of analysis was include also transport of slop grains from Krasnystaw distillery at the distance of $98 \mathrm{~km}$ (both $196 \mathrm{~km}$ in total) and sugar beet pulp from the sugar factory in Suchowola at a distance of $19.2 \mathrm{~km}(38.4 \mathrm{~km})$.

Outside the system boundaries were treatments related to the application of digestive sludge in the field. At the same time, in the analysis was included so called avoided emissions associated with the production of mineral fertilizers, which are substitutes for biogas digesters.

For the technological stage, $1 \mathrm{MWh}$ of electricity generated from biogas was used as a functional unit.

\section{Method of environmental life cycle assessment}

The SimaPro software, one of the widely used and common tools to perform the LCA analysis, developed by the Dutch company Pré Consultants was used in the research [10].

In SimaPro programme several methods, to assess the product life cycle impact, is available. They differ significantly, so it is necessary to determine the priorities of the LCA analysis. When choosing a method for performing the life cycle impact assessment (LCIA) as well as the impact categories, it is essential to take into consideration the goal and scope of the analysis [5]. Aspects that should be taken into consideration when choosing the appropriate method are as follows: the way of presentation of the final results, a method of weighting, timeframe outlined, geographical coverage, the degree of accuracy and impact categories considered.

Consequently, after analyzing the methods available in the SimaPro program, the Eco-Indicator 99 (e-indicator method) was considered the most appropriate. This method is aimed at assessing damage both to the environment as 
well as to the human This method gives three endpoints defined as ecological impact results (Table 1) [10, 11]:

- human health expressed in DALY unit (Disability Adjusted Life Years) used by the WHO and the World Bank in health statistics;

- ecosystem quality (in categories: acidification, eutrophication and land use) - the value of the damage is given in PDF unit (Potentially Dissapeard Fraction); for ecotoxicity damage is expressed in PAF $\times \mathrm{m}^{2} \times$ year unit, showing the percentage of species living in the environment under the toxic stress);

- depletion of natural resources (unit: $\mathrm{MJ} / \mathrm{t}$ ).

Each of the endpoints contains the corresponding categories of impact assigned to it. Those particularly important in the life cycle assessment of the electricity production from agriculture biogas are given in bold in Table 1 .

Table 1. Endpoints and assigned them impact categories and indicators in Eco-Indicator 99 method [10]

\begin{tabular}{|c|c|c|}
\hline Endpoints & Impact categories & Indicator \\
\hline HUMAN & $\begin{array}{c}\text { Climate change, ozone } \\
\text { layer depletion, carcin- } \\
\text { ogens, respiratory organ- } \\
\text { ics and inorganics, } \\
\text { radiation }\end{array}$ & DALY \\
BIODIVERSITY & $\begin{array}{c}\text { Acidification, eutro- } \\
\text { phisation, land use, } \\
\text { ecotoxitity }\end{array}$ & $\begin{array}{c}\text { PDF (eutrophisa- } \\
\text { tion, acidification } \\
\text { and land use) } \\
\text { PAF } \times \mathrm{m}^{2} \times \text { year } \\
(\mathrm{ecotoxitity)}\end{array}$ \\
\hline RESOURCE & $\begin{array}{c}\text { Reducing the amount } \\
\text { of minerals and fossil } \\
\text { fuels }\end{array}$ & $\mathrm{MJ} / \mathrm{t}$ \\
\hline
\end{tabular}

\subsection{Environmental impact categories of}

In the Eco-Indicator 99 method in the SimaPro program are available a lot of impact categories (Table 2) [10]. To show the impact of maize cultivation and the production of electricity from biogas on the environment, it is necessary to select some of the most important impact category, from taking into account the purpose of analysis. The following influence categories were selected:

- climate change,

- ozone layer depletion,

- eutrophisation/acidification,

- land use,

- reducing the amount of minerals and fossil fuels.

Table 2. The impact categories in the Eco-Indicator 99 method [10]

\begin{tabular}{|c|l|}
\hline Impact category & \multicolumn{1}{|c|}{ Inputs and outputs (LCI) } \\
\hline climate change & $\begin{array}{l}\text { carbon dioxide }\left(\mathrm{CO}_{2}\right), \text { nitrogen } \\
\text { dioxide }\left(\mathrm{NO}_{2}\right), \text { mathane }\left(\mathrm{CH}_{4}\right), \\
\text { chlorofluorocarbon }(\mathrm{CFC}), \text { hydro- } \\
\text { chlorofluorocarbon }(\mathrm{HCFC})\end{array}$ \\
\hline ozone layer depletion & $\begin{array}{l}\text { chlorofluorocarbon }(\mathrm{CFC}), \text { hydro- } \\
\text { chlorofluorocarbon }(\mathrm{HCFC}), \text { halons }\end{array}$ \\
\hline acidification & $\begin{array}{l}\text { Sulfur oxides }\left(\mathrm{SO}_{\mathrm{x}}\right), \text { nitrogen oxides } \\
\left(\mathrm{NO}_{\mathrm{x}}\right), \text { ammonia }\left(\mathrm{NH}_{4}\right)\end{array}$ \\
\hline eutrophication & $\begin{array}{l}\text { nitrogen oxides }\left(\mathrm{NO}_{\mathrm{x}}\right), \text { ammonia } \\
\left(\mathrm{NH}_{4}\right), \text { phosphate }\left(\mathrm{PO}_{4}\right), \text { nitrates }\end{array}$ \\
\hline fossil fuel depletion & $\begin{array}{l}\text { the amount of fossil fuels and } \\
\text { minerals used }\end{array}$ \\
\hline land use & $\begin{array}{l}\text { area of the land used for crops as } \\
\text { well as its transformation and } \\
\text { degree of transformation }\end{array}$ \\
\hline
\end{tabular}

Climate change. This impact category is characterized by an index defined by the sum of the greenhouse effect values for the substance over the years, including the pollutant (in $\mathrm{kg}$ ). This indicator is therefore a development of the popular Global Warming Potential indicator(GWP). This indicates strong, and sometimes direct, connection to the amount of greenhouse gases emitted to the atmosphere, mainly $\mathrm{CO}_{2}$ and $\mathrm{CH}_{4}$.

The indicators for the global warming group are carbon dioxide $\left(\mathrm{CO}_{2}\right)$, nitrogen dioxide $\left(\mathrm{NO}_{2}\right)$, methane $\left(\mathrm{CH}_{4}\right)$, chlorofluorocarbons (CFC), hydrochlorofluorocarbons (HCFC), and methyl bromide $(\mathrm{CH} 3 \mathrm{Br})$. Each of the indiindicators is transformed into Eco-Indicator 99 to a characterization factor, which is equivalent to carbon dioxide $\left(\mathrm{CO}_{2}\right)[5,10]$.

The ozone layer depletion is described as a indicator defined as the equivalent of the potential reduction of the ozone layer in the case of the disintegrated substance, together with the amount of pollution it cause (its quantity in $\mathrm{kg}$ ). This indicator also define as indicator of stratospheric ozone depletion. Stratospheric ozone is a direct "barrier" to ultraviolet radiation reaching the surface of the Earth. Increasing the intensity of ultraviolet radiation cause harmful effects on humans, animals and plants. The emission of greenhouse gases by industry and agriculture is very significant for the reduction of the ozone layer. Energy-intensive technologies in agriculture and the frequent use of plant growth substances contribute to the depletion of the ozone layer in the final analysis. The effects of depletion of the ozone layer affect entire aquatic and terrestrial ecosystems, biochemical cycles, and indirectly on crop growth and productivity decline.

Ozone-depleting indicators are chlorofluorocarbons (CFCs), hydrochlorofluorocarbons (HCFCs), halons and methyl bromide $\left(\mathrm{CH}_{3} \mathrm{Br}\right)$. Each of the above ratios is converted into a characterization factor, the equivalent of trichlorofluoromethane (CFC-11).

Eutrophication is the process of enriching natural water body into nutrients (nutrients, biogens) resulting in trophic growth or water fertility. This process also applies to natural watercourses. The main cause of eutrophication is the increasing load of biogenic elements, primarily nitrogen and phosphorus. Large amounts of phosphorus are associated with intensification of fertilization and increased erosion in the catchments. The increase in nitrogen supply is connected whereas with the increasing emission of nitrogen oxides into the atmosphere and thus their high content in atmospheric precipitation. Fertilizing the soil under cultivation also contributes to the growth of the nitrogen load. Heavy rainfall can easily wash out nitrogen from the surface layer of the soil and from fertilizers, while large amounts of phosphorus can also be brought into the tank. The main source of these compounds in the environment are fertilizers used in agriculture [5]. Considering the impact of production lines on eutrophication is therefore justified because of the use of energy crops.

Acidification is a phenomenon caused by excessive emissions of sulfur dioxide $\left(\mathrm{SO}_{2}\right)$, nitrogen oxides $\left(\mathrm{NO}_{\mathrm{x}}\right)$ and ammonia $\left(\mathrm{NH}_{3}\right)$. Due to the fact that the combustion of fossil fuels contributes to high emissions especially of sul- 
fur compounds, it is proposed to include the acidification category in environmental analysis. In addition, the use of fertilizers in agriculture is associated with $\mathrm{NH}_{3}$ emissions. The excess of acidic compounds has a negative effect, among others. For surface and ground waters, soil, flora and fauna [12].

Reduce mineral resources and reduce fossil fuel resources. The natural resource reduction index is considered in the LCA method both globally and regionally and locally.

The use of land should be understood both to occupy land for crops and to transpose it from one type of use to another. The increase in the number of people contributing to the increase in the demand for food brings with it the inevitable need for the development of agriculture and the extractive industries in order to meet the needs of food and energy. It involves a great deal of the necessity of managing the ever larger area of the earth and its continuous transformation. The characterization index for the land use category is the development and degree of land conversion expressed in $\mathrm{m}^{2}$.

\section{Results}

The results of the LCA analysis concern the environmental impact of the impact categories identified in the LCA analysis of the Eco-Indicator 99 method. They are presented in two variants: characterization and normalization. For a fuller picture of the results obtained, Sankey's graphs of material and energy flow for the biogas power generation process from different substrates are also included. Results are expressed in units assigned to each impact category. On the basis of these values it is possible to determine whether the advantage of the process of generating electricity from biogas derived from waste materials over the process of generating electricity from biogas obtained from maize silage expressed in much lower values of environmental indicators is unequivocal at the level of particular categories influence. Due to the fact that the categories are expressed in different units, they can not be compared to each other. The results below are expressed as a percentage of the highest result in a given benchmark category and are considered as a $100 \%$.

In the Figure 3 we can see results of comparison life cycle assessment of $1 \mathrm{MWh}$ of electricity production from biogas obtain from corn silage, distillery slop and sugar beet pulp as well as pig manure distillery slop and sugar beet pulp for each impact category in EI-99 method.

As the following figure shows the categories that have the greatest negative impact on the environment is climate change and land use. This result is related to the necessity of intending land for corn cultivation and the use of mineral fertilizers and plant protection products, which production and application of the plantation is energy-intensive and results in significant emissions of particulate matter and gases into the air. For result of the analysis significant influence has also the fuel combustion, mainly diesel fuel, during field work and raw material transport to the biogas plant. In the case of other impact categories, both for electricity from biogas produced from waste materials, such as corn silage the results are positive, which is connected with taking into account in the analysis so-called avoided production of ammonium nitrate, thanks to use post- fermentation digestate as fertilizer, and the replacement of heat from coal, through the use of waste heat producing in a biogas plant.

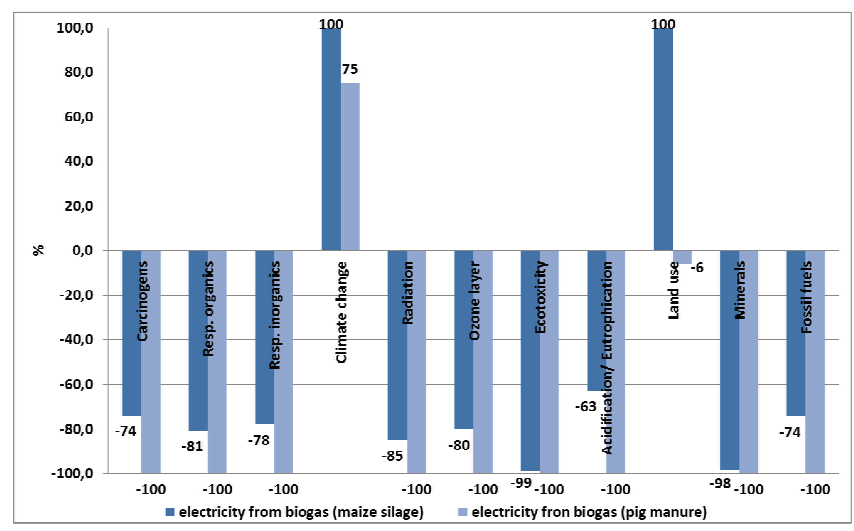

Fig. 3. Results of comparison life cycle assessment of $1 \mathrm{MWh}$ of electricity production from biogas obtain from corn silage, distillery slop and sugar beet pulp ale well as pig manure distillery slop and sugar beet pulp for each impact category in EI-99 method (characterization)

In the climate change category the result is related to the use of diesel fuel to power agricultural machinery at different stages of corn cultivation for silage, starting from field work to prepare the land for cultivation, by planting, treatments associated with fertilization and application of plant protection products, harvesting, as well as raw materials transport (with fields, from sugar refinery and distilleries) to the plant. In this category is also very important production and use of mineral fertilizers and plant protection products.

In the land use category the result is significantly higher for electricity produced from biogas produced from corn silage. It is associated with the necessity of intending land for corn cultivation.

In addition, the previously mentioned impact categories, such as ozone layer depletion, eutrophication/acidification and depletion of minerals and fossil fuel resources should be also taking into account.

Ozone layer depletion category is closely related to greenhouse gas emissions arising from the combustion of diesel fuel during field work and raw material transport to the biogas plant, as well as extremely energy-intensive manufacturing of fertilizers and plant protection products, and their use in the field.

For the eutrophication / acidification impact category and the reduction of mineral resources the greatest impact has production and use of mineral fertilizers and plant protection products, which application is required during corn cultivation. Part of the dose of fertilizers and plant protection products is not absorbed by the plants and gets into the groundwater or is leached from the soil by rainfall and runoff goes into rivers, lakes and seas.

The assumptions show that category, which has a significant impact on the environment is a "reduction of fossil fuels". It is connected witch the use of diesel fuel to power agricultural machinery at different stages of corn cultivation for silage and its transport to the biogas plant at a distance of $12 \mathrm{~km}$ in both directions. Founded transport distance for distillery slop and sugar beet pulp is significant and 
amounts to 196 and $38.4 \mathrm{~km}$ in both directions. In order to use of diesel fuel it is necessity of obtaining fossil fuels needed to produce the fuel. Taking into account the aggregate fuel consumption during field work and transport of corn silage to biogas plant and comparing them with the fuel consumption during transportation of sugar beet pulp and distillery slop, we obtain the value of the index for the category at a similar level.

Sankey graph (Fig. 4) generated based on material and energy balance of the electricity production process from biogas produced from corn silage, distillery slop and sugar beet pulp shows the percentage of individual processes and emissions in overall effect associated with the environmental impact of mentioned process. As the following graph shows the greatest impact on the environment have material and energy inputs and emissions from the cultivation of maize for silage and its transport from the field to the biogas plant (it is $55.5 \%$ of the total environmental impact of electricity production from biogas). The graph also shows that the positive environmental impact is associated with the consideration in the analysis of avoided production of ammonium nitrate and heat from coal.

Sankey graph is presented with regard to the processes / factors which impact is not less than 9\% (cut-off $9 \%$ ).

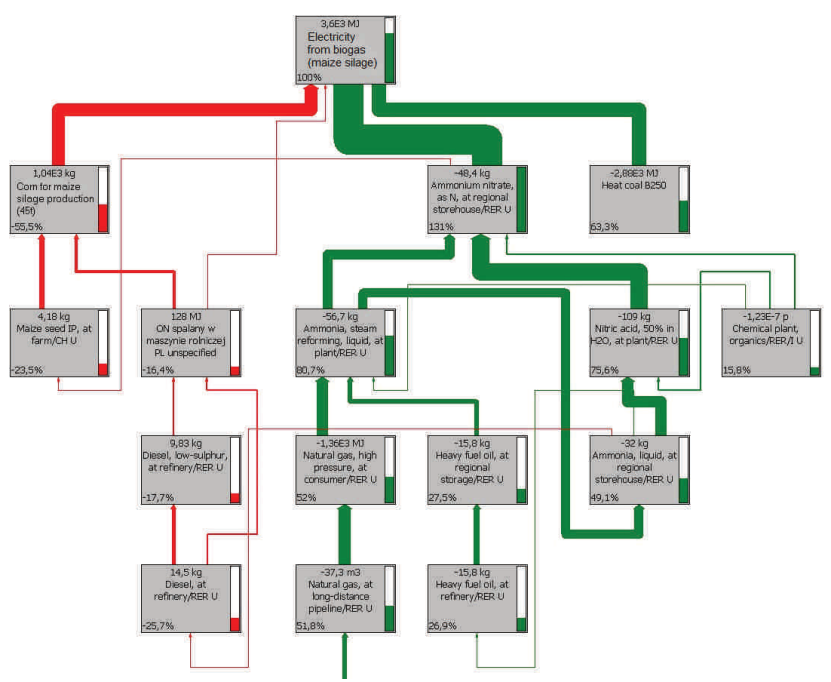

Fig. 4. Sankey graph for $1 \mathrm{MWh}$ of electricity production from biogas obtain from corn silage, distillery slop and sugar beet pulp (materialenergy balance fragment)

From the Sankey graph (Fig. 5), for the process of electricity production from biogas used as an engine fuel, where maize silage was replaced with pig slurry, it is clear that the most significant environmental impacts are material and energy inputs and emissions associated with the burning of diesel during transport of sugar beet pulp to the biogas plant (it is $7.58 \%$ of the total environmental impact of the biogas power generation process). This graph also shows that the positive impact on the environment associated with avoiding the ammonium nitrate production and the avoidance of heat generation from hard coal.

Sankey graph is presented with regard to the processes / factors which impact is not less than 5\% (cut-off 5\%).

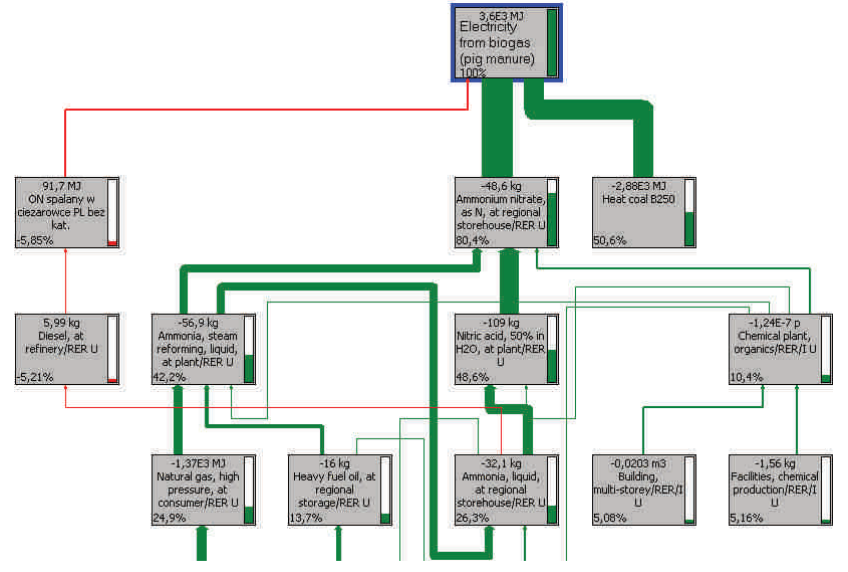

Fig. 5. Sankeya graph for $1 \mathrm{MWh}$ of electricity production biogas obtain from pig slurry, distillery slop and sugar beet pulp ((material-energy balance fragment)

Figure 6 presents LCA results for endpoints within the used Eco-Indicator 99 method, such as human health, ecosystem quality and reduced natural resources. The obtained values of the ecoindicator [Pkt] are expressed in the general unit - the points determining the size of the impact on the environment. Changing the results expressed in different units [DALY, PDF, PAF or MJ] is done after the normalization process [4].

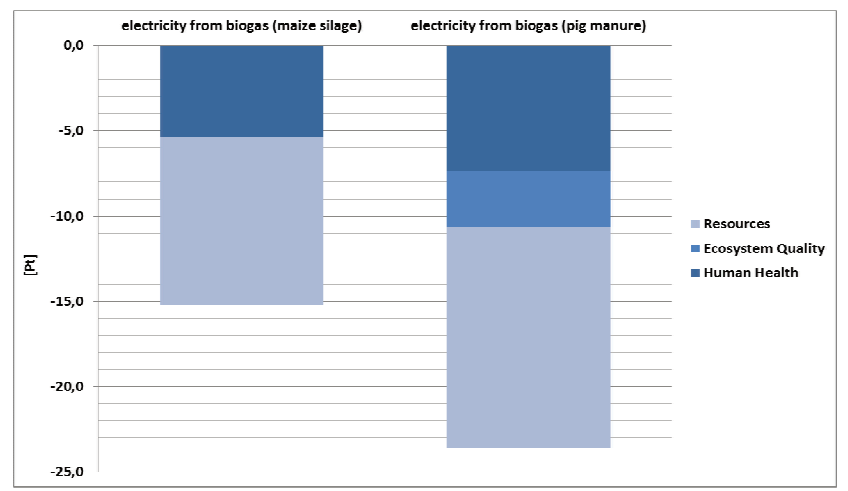

Fig. 6. Results of a comparative analysis of a $1 \mathrm{MWh}$ of electricity production from biogas obtain from corn silage, distillery slop and sugar beet pulp as well as from pig slurry, distillery slop and sugar pulp for individual EI - 99 impact categories (normalization)

As is evident from the graph below, the environmental impact of individual endpoints, especially human health and resources, is positive for both type of biogas (from corn and from wastes). This result is conditioned by taking into account in the analysis of the avoided production of ammonium nitrate and heat from hard coal using the digestate sludge as a fertilizer and the management of waste heat.

\section{Conclusions}

In this publication the results of simplified life cycle assessment analysis for electricity production from agricultural biogas obtain through $\mathrm{WtE}$ processes was presented. The main stages and unit processes of the technology were also defined, as well as system boundaries, material and energy inputs and emissions to water, soil and air. 
The results show that the greatest impact on the environment have two unit processes connected with the cultivation of corn for ensiling purposes. This result is related to the necessity of intending land for corn cultivation and the use of mineral fertilizers and plant protection products, which production and application of the plantation is energy-intensive and results in significant emissions of particulate matter and gases into the air. For result of the analysis significant influence has also the fuel combustion, mainly diesel fuel, during field work and raw material transport to the biogas plant.

It is also worth to underline that the positive impact on the environment of electricity producing process from bio- gas obtained from both type of substrate is determined by taking into account on the analysis the avoided production of ammonium nitrate and heat from hard coal thanks to Use of post-fermentation sludge as a fertilizer and management of waste heat generated in biogas plants. It shows how important it is from an environmental point of view to manage all possible waste and by-products generated during this process. It also draws attention to waste as a valuable source of energy and recyclable substrates, which in relation to sustainable development is particularly important, because it combines all the key elements of the sustainable development concept.

\section{Nomenclature}

LCC life cycle cost

LCIA life cycle inventory analysis

WtE waste to energy

DALY disability adjusted life years

PDF potentially dissapeard fraction

ODP ozone layer depletion

GWP global warming potential

ON diesel fuel

$\mathrm{CO}_{2} \quad$ carbon dioxide
$\mathrm{NO}_{\mathrm{x}} \quad$ nitrogen oxides

$\mathrm{NO}_{2}$ nitrogen dioxide

$\mathrm{SO}_{2} \quad$ sulphur dioxide

$\mathrm{CH}_{4}$ methane

CFC chlorofluorocarbon)

HCFC hydrocholorofluorocarbon

$\mathrm{CH}_{3} \mathrm{Br}$ methyl bromide

$\mathrm{NH}_{3}$ ammonia

\section{Bibliography}

[1] SAMSON-BRĘK, I. Zastosowanie metody oceny cyklu życia LCA do oszacowania wpływu na środowisko wytwarzania paliwa biogazowego do silników spalinowych. Archiwum Motoryzacji. 2011, 2(53), 69-79.

[2] BIERNAT, K., GIS, W., SAMSON-BRĘK, I. Application of the life cycle assessment (LCA) method to the estimation of environmental impact of the engine biofuels generation for example of biogas fuel. Combustion Engines. 2012, 148(1), 25-32.

[3] GÓRZYŃSKI, J. Podstawy analizy środowiskowej wyborów i obiektów. Wydawnictwa Naukowo-Techniczne. Warszawa 2007.

[4] LEWANDOWSKA, A. Środowiskowa Ocena Cyklu Życia Produktu na przykładzie wybranych typów pomp przemysłowych. Wydawnictwo Akademii Ekonomicznej. Poznań 2006.

[5] GÓRALCZYK, M., KOWALSKI, Z., KULCZYCKA, J. Ekologiczna ocena cyklu istnienia procesów wytwórczych (LCA). Wydawnictwo Naukowe PWN. Warszawa 2007.

Prof. Zdzisław Chłopek, DSc., DEng. - Faculty of Automotive and Construction Machinery Engineering at Warsaw University of Technology.

e-mail: Z.Chlopek@pimot.eu

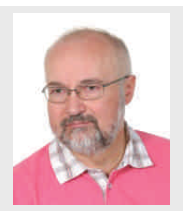

[6] FAVA, J. A technical framework for life-cycle assessment. In: SETAC and SETAC Foundation for Environmental Education, Washington 1991.

[7] SZKODA, M. Analiza kosztu cyklu trwałości (LCC) w ocenie efektywności środków transportu szynowego. Logistyka. 2011, 3.

[8] PN-EN 60300-3-3:2006 - Zarządzanie niezawodnością Część 3-3: Przewodnik zastosowań - Szacowanie kosztu cyklu życia.

[9] Life cycle cost handbook - guidance for life cycle cost estimation and analysis, office of acquisition and project management. U.S. Department of Energy. Washington, 2014.

[10] GOEDKOP, M., SPRIENSMA, R. The eco-indicator 99. A damage oriented method for life cycle assessment. Methodology report, PRé Consultants B.V. Netherlands 2000.

[11] LINDFORS, L.G. Nordic guidelines on life-cycle assessment. Nordic Council of Minister. Copenhagen 1995.

[12] SENSI, A. Eurostat, agriculture and acidification. European Commission. ec.europa.eu/agriculture/envir/report/en/acid_en/ report.htm\#Foot3a.

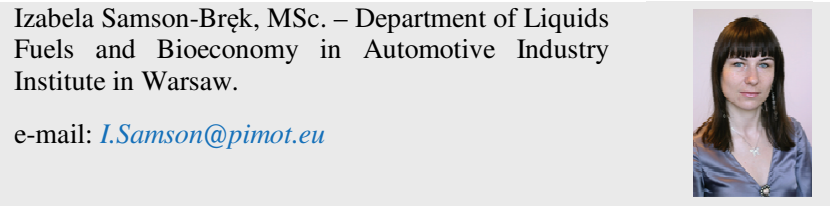

